\section{Commentary: Just because we can, doesn't always mean we should}

\author{
Joseph R. Nellis, MD, MBA, ${ }^{a}$ and \\ Joseph W. Turek, MD, PhD, MBA ${ }^{\mathrm{a}, \mathrm{b}, \mathrm{c}}$
}

The article by Farias and colleagues, ${ }^{1}$ "Clinical updates on the hybrid comprehensive stage II operation," highlights a common issue within pediatric heart surgery-improving outcomes for low-frequency, high-impact operations. The volume-outcome relationship in pediatric heart surgery is well established. Greater-volume centers are associated with reduced length of stay, cost of care, morbidity, and mortality. ${ }^{2-6}$ And despite the evidence, 117 of the 119 programs that participate in public reporting perform STAT- 5 cases, with the average program only performing 8 cases per year. ${ }^{7}$ As surgeons, we understand that practice makes perfect, but with more than $60 \%$ of programs located within 25 miles of one another, programmatic volume isn't always under our control. ${ }^{8}$ Therefore, as surgeons, we start exploring innovative approaches to traditional repairs hoping to find a safer way forward.

In this issue of JTCVS Open, Farias and colleagues ${ }^{1}$ describe their experience performing the hybrid comprehensive stage II procedure for patients with hypoplastic left heart syndrome. The authors developed the approach to simplify the procedure and avoid cardioplegia, arch reconstruction, and Damus-Kaye-Stansel creation for patients with adequate antegrade native aortic flow. While the first patient died, the following 3 patients successfully underwent Fontan and are doing well 3 and a half to 6 years later. The authors should be commended

From the ${ }^{\mathrm{a}}$ Duke Congenital Heart Surgery Research \& Training Laboratory and ${ }^{\mathrm{b}} \mathrm{Di}-$ vision of Thoracic and Cardiovascular Surgery, Duke University; and ${ }^{\mathrm{c}}$ Duke Children's Pediatric \& Congenital Heart Center, Duke Children's Hospital, Durham, NC.

Disclosures: The authors reported no conflicts of interest.

The Journal policy requires editors and reviewers to disclose conflicts of interest and to decline handling or reviewing manuscripts for which they may have a conflict of interest. The editors and reviewers of this article have no conflicts of interest.

Received for publication May 4, 2021; revisions received May 4, 2021; accepted for publication May 10, 2021; available ahead of print May 25, 2021.

Address for reprints: Joseph W. Turek, MD, PhD, MBA, Division of Thoracic and Cardiovascular Surgery, Duke University Medical Center, 2301 Erwin Rd, DUMC 3474, Durham, NC 27710 (E-mail: joseph.turek@duke.edu).

JTCVS Open 2021;7:336-7

2666-2736

Copyright (C) 2021 The Author(s). Published by Elsevier Inc. on behalf of The American Association for Thoracic Surgery. This is an open access article under the CC BY-NC-ND license (http://creativecommons.org/licenses/by-nc-nd/4.0/).

https://doi.org/10.1016/j.xjon.2021.05.003

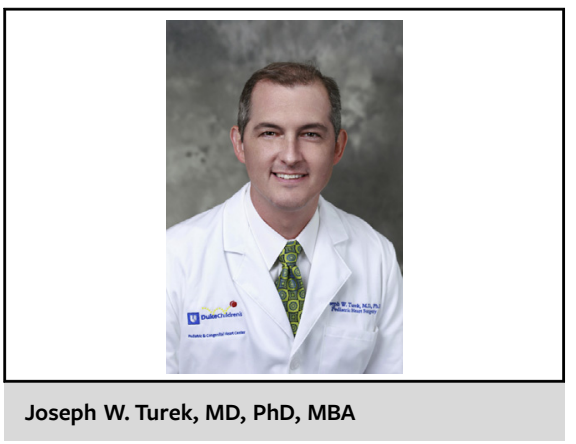

CENTRAL MESSAGE

Smaller innovative series need to

be published. Surgeons need

feedback to ensure that the risks

and benefits of new repairs al-

ways favor the patient. Without

feedback, errors in judgment can

occur.

on their approach and their willingness to share their experience.

Learning curves exist, and early complications shouldn't hold back innovative approaches, particularly those in complex pediatric heart surgery. The authors appropriately addressed the complication with their first case and acknowledge that the high reintervention rate (14 catheterizations, 14 dilations, and 13 stents between three patients) is concerning. No program has the volume to detect a 2 -fold increase, let alone a $5 \%$ increase in mortality for any repair. ${ }^{9}$ Therefore, at the individual surgeon level, the decision to offer these repairs will always be subjective, emphasizing the importance of supporting this conversation in a public forum.

The authors should be cautious, however, in that the complications that originally prompted development of the hybrid comprehensive stage II repair may not be technical in nature. The volume-outcome relationship can be either surgeon-specific (eg, the arterial switch operation) or center-specific (eg, neonatal open heart or the Norwood). ${ }^{2-4}$ Without careful analysis of the underlying relationship, new and at times dangerous surgical alternatives might be inappropriately used, potentially increasing the complication rate. If outcomes for the comprehensive stage II procedure are like the Norwood, then the postoperative care a patient receives is more influential in their outcome than the technical nuances of their case. In which case, best practice implementation in the intensive care unit may 
have greater impact than a novel surgical approach. Although regardless of the underlying relationship, if the authors are only performing 4 cases every 6 years, it may be more reasonable to develop a regional referral strategy, as experienced centers have reported $5 \%$ operative mortality and minimal catheter-based reintervention rates following comprehensive stage II repair. ${ }^{10}$

\section{References}

1. Farias M, Fleishman CE, Nykanen D, DeCampli WM. Clinical update on the hybrid comprehensive stage II operation. J Thorac Cardiovasc Surg Open. 2021;7:327-35.

2. Karamlou T, Jacobs ML, Pasquali SK, He X, Hill K, O'Brien S, et al. Surgeon and center volume influence on outcomes after arterial switch operation: analysis of the Society of Thoracic Surgeons congenital heart surgery database. Ann Thorac Surg. 2014;98:904-11.

3. Kansy A, Zu Eulenburg C, Sarris G, Jacobs JP, Fragata J, Tobota Z, et al. Higher programmatic volume in neonatal heart surgery is associated with lower early mortality. Ann Thorac Surg. 2018;105:1436-40.
4. Checchia PA, McCollegan J, Daher N, Kolovos N, Levy F, Markovitz B. The effect of surgical case volume on outcome after the Norwood procedure. $J$ Thorac Cardiovasc Surg. 2005; 129:754-9.

5. Pasquali SK, He X, Jacobs ML, Shah SS, Peterson ED, Gaies MG, et al. Excess costs associated with complications and prolonged length of stay after congenital heart surgery. Ann Thorac Surg. 2014;98:1660-6.

6. Jacobs JP, O'Brien SM, Pasquali SK, Jacobs ML, Lacour-Gayet FG, Tchervenkov CI, et al. Variation in outcomes for benchmark operations: an analysis of the STS Congenital Heart Surgery Database. Ann Thorac Surg. 2011;92: 2184-92.

7. Jacobs JP, Mayer JE, Pasquali SK, Hill KD, Overman DM, St Louis JD, et al. The Society of Thoracic Surgeons Congenital Heart Surgery Database: updated on outcomes and quality. Ann Thorac Surg. 2019;107:691-704.

8. Welke KF, Pasquali SK, Lin P, Backer CL, Overman DM, Romano JC, et al. Hospital distribution and patient travel patterns for congenital cardiac surgery in the United States. Ann Thorac Surg. 2019;107:574-82.

9. Welke KF, Karamlou T, Ungerleider RM, Diggs BS. Mortality rate is not a valid indicator of quality differences between pediatric cardiac surgical programs. Ann Thorac Surg. 2010;89:139-46.

10. Yerebakan C, Valeske K, Elmontaser H, Yörüker U, Mueller M, Thul J, et al. Hybrid therapy for hypoplastic left heart syndrome: myth, alternative, or standard? J Thorac Cardiovasc Surg. 2016;151:1112-23. 